\title{
Sea level, biotic and carbon-isotope response to the Paleocene-Eocene thermal maximum in Tibetan Himalayan platform carbonates
}

\author{
Juan $\mathrm{Li}^{\mathrm{a}}$, Xiumian $\mathrm{Hu}^{\mathrm{a},{ }^{*}}$, James C. Zachos ${ }^{\mathrm{b}}$, Eduardo Garzanti ${ }^{\mathrm{c}}$, Marcelle BouDagher-Fadel ${ }^{\mathrm{d}}$ \\ ${ }^{a}$ State Key Laboratory of Mineral Deposit Research, School of Earth Sciences and Engineering, Nanjing University, Nanjing 210023, China \\ ${ }^{\mathrm{b}}$ Department of Earth and Planetary Sciences, University of California Santa Cruz, 1156 High Street, Santa Cruz, CA 95064, USA \\ ${ }^{\mathrm{c}}$ Laboratory for Provenance Studies, Department of Earth and Environmental Sciences, Università di Milano-Bicocca, 20126 Milano, Italy \\ ${ }^{\mathrm{d}}$ Department of Earth Sciences, University College London, London WC1H OBT, UK
}

\begin{abstract}
A B S T R A C T
During the Paleocene-Eocene Thermal Maximum (PETM, 56 Ma), a large, negative carbon-isotope excursion (CIE) testifies to a massive perturbation of the global carbon cycle. Shallow-marine settings are crucial to understand the environmental and ecological changes associated with the PETM and the connection between continental and open-marine environments. Detailed sedimentological, paleontological, and geochemical analysis of a quasi-continuous succession of shallow-marine carbonates in the Tethys Himalaya of southern Tibet indicates that a relative rise in sea level coincided with PETM onset, continued through PETM core, and terminated with a regression at PETM recovery. At PETM onset, corresponding to the SBZ4/SBZ5 boundary, no obvious impact on biota and specifically on larger benthic foraminifera (LBF) is observed. The major biotic change occurs later on at PETM recovery, corresponding to the SBZ5/SBZ6 boundary. Our data suggest that relative sea level, rather than temperature, exerted the main control on benthic biota during the PETM. Although the $\delta^{13} \mathrm{C}_{\text {org }}$ values of organic matter are similar in the deep sea and shallow-marine continental margins, the

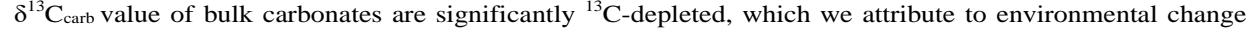
driven by relative sea-level fluctuations.
\end{abstract}

\section{Introduction}

The Paleocene-Eocene thermal maximum (PETM; 56 Ma) is considered to be an excellent time interval for studying the dynamics of rapid greenhouse warming (Zachos et al., 2008) and thus a useful analogue to predict the future impact of global change (Zeebe and Zachos, 2013; Zeebe et al., 2016). Hallmarks of the PETM are the negative carbon-isotope excursion and widespread dissolution of pelagic carbonates (Zachos et al., 2005), processes both attributed to the rapid injection of ${ }^{13} \mathrm{C}$-depleted carbon (as $\mathrm{CO}_{2}$ and/or $\mathrm{CH}_{4}$ ) into the global exogenic carbon pool (Dickens et al., 1997). About $170 \mathrm{kyr}$ after the event onset (Zeebe and Lourens, 2019), carbonate productivity and carbon-isotope ratios returned close to pre-event values, indicating near complete sequestration of excess carbon. Enhanced silicate weathering is invoked as the main mechanism for this recovery (Dickens et al., 1997; Kelly et al., 2005; Penman et al., 2016), although significant amounts of carbon were likely sequestered into organic-carbon reservoirs as well (John et al., 2008; Sluijs et al., 2008a; Komar and Zeebe, 2017).
The Fifth Assessment Report (AR5) of the Intergovernmental Panel on Climate Change (IPCC, 2013) concluded that anthropogenic warming is likely to exceed $2{ }^{\circ} \mathrm{C}$ above pre-industrial temperatures by 2100 , with a corresponding sea-level rise exceeding $2 \mathrm{~m}$. A sea-level rise of this magnitude would clearly have profound consequences, including a land loss of $\sim 1.8$ million $\mathrm{km}^{2}$ comprising critical regions of food production and displacement of up to 187 million people. Shallowmarine records are key to understanding the combined land-sea impacts on ecologically sensitive coastal environments. Sea-level rise during the PETM may be considered a useful analogue to predict the future impact of global warming. Studies of shallow marine sections were carried out in northern Spain (Schmitz and Pujalte, 2003, 2007; Scheibner et al., 2007), Egypt (Speijer and Wagner, 2002; Scheibner et al., 2005), Tunisia (Stassen et al., 2012a), SW Slovenia (Zamagni et al., 2012), Tibetan Himalaya (Li et al., 2017; Zhang et al., 2018), and North America (Sluijs et al., 2008b, 2014; Stassen et al., 2012b), adding to the understanding of the response of benthic biota to the PETM. However, the isotopic expression of the PETM and the environmental impact of this major thermal event have remained largely elusive in shallow marine

\footnotetext{
${ }^{*}$ Corresponding author.

E-mail address: huxm@nju.edu.cn (X. Hu).
} 


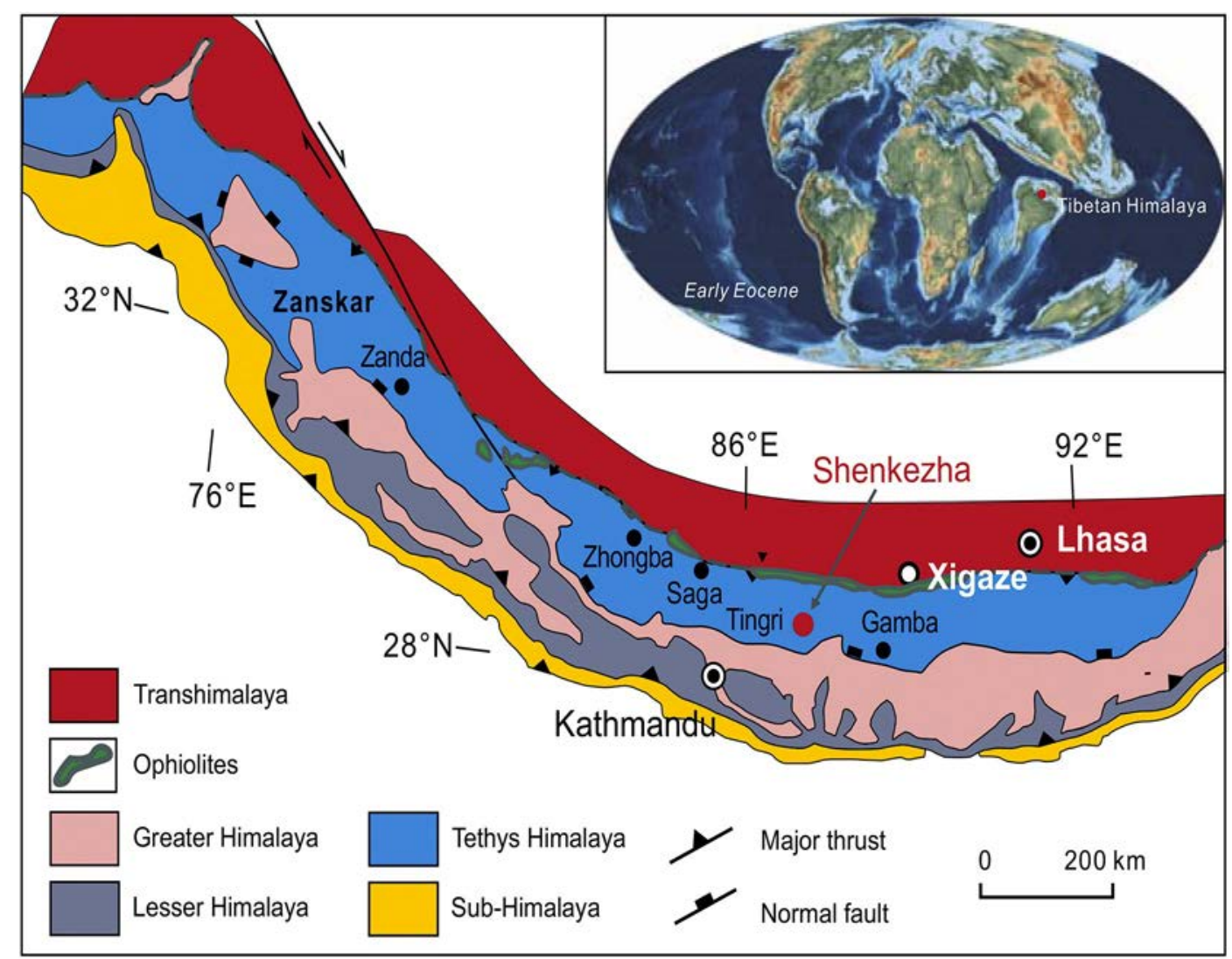

Fig. 1. Geological sketch map of the Himalayan Range (after Gansser, 1964) showing the studied Shenkezha stratigraphic section in southern Tibet. Inset shows the envisaged early Eocene paleogeography with location of Tibetan Himalaya.

carbonate platform, particularly as the biotic response to sea-level change is concerned.

In this study, we present new sedimentological, paleontological, and geochemical evidence from a shallow-water carbonate platform exposed in Tethyan zone of the Tibetan Himalaya (Fig. 1). In this region, accumulation of thick, shallow-water marine carbonates throughout the latest Paleocene and earliest Eocene and abundance of large benthic foraminifera offers the rare opportunity to perform a high-resolution study documenting: 1) the biotic response to sea-level change in shallow-marine environments during the PETM; and, 2) the carbonisotope expression of the PETM in a shallow-water carbonate platform. Our findings provide valuable insight into the impact of warming climate on Tethyan carbonate platforms and allow us to draw more general conclusions about the possible discrepancies between the geochemical record of shallow-water carbonates and global ocean chemistry.

\section{Geological setting and methodological approach}

Our study area is located in the Tethys Himalaya sedimentary zone of southern Tibet, which contains the remnants of the passive continental margin of India facing the Neotethys Ocean (Sciunnach and Garzanti, 2012). Carbonate platforms developed from the middle Paleocene to the early Eocene are very well exposed in the southern part of the Tethys Himalaya (Nicora et al., 1987; Hu et al., 2012). These units are traced laterally over long distances, testifying to the widespread distribution of platform carbonates in the Tethyan realm at this time (Li et al., 2017) (Fig. 1). The uppermost Paleocene to lowermost Eocene Shenkezha section located in the Tingri area of southern Tibet (N 28 $8^{\circ} 41^{\prime \prime} 33^{\prime \prime}$, E 86 $86^{\circ} 2.6^{\prime \prime}$ ) is illustrated in detail in this article (Fig. 2A), focusing on an $18 \mathrm{~m}$-thick unit of nodular limestone and marly nodular limestone (Fig. 2B) overlain by $6 \mathrm{~m}$ of thick-bedded or massive limestone (Fig. 2C). In this study, we integrate larger-benthicforaminifera (LBF) biostratigraphy with stable-carbon-isotope stratigraphy to robustly constrain the depositional age of strata, present a careful sedimentological analysis to reconstruct environmental changes, and use the $\mathrm{C} / \mathrm{N}$ ratio to trace the source of organic matter.

In order to reconstruct the environmental evolution throughout the studied section, carbonate-microfacies analysis was performed by examining detrital minerals, biotic assemblages, and textures as observed in both thin sections and outcrops, described based on Dunham's (1962) classification extended by Embry and Klovan (1971), and interpreted according to Flügel (2010).

Larger-benthic-foraminiferal analysis was based on key morphological characteristics including coiling mode, peripheral shape, arrangement and number of chambers, presence or absence of keels, and sutural properties. All the species are index fossils of the Tethyan shallow benthic zonation (SBZ) established by Serra-Kiel et al. (1998) and tied to the time scale of Gradstein et al. (2012).

Bulk-carbonate and organic-matter carbon-isotope analysis were performed at the State Key Laboratory for Mineral Deposits Research at Nanjing University. Carbonates were analyzed with an in-line GasBench II auto sampler coupled to a Finnigan MAT Delta Plus XP mass spectrometer. Powdered samples were reacted with purified orthophosphoric acid at $70{ }^{\circ} \mathrm{C}$. Data are expressed in standard delta notation $(\delta)$, as per mil deviations from the Vienna Pee Dee Belemnite (VPDB) standard. Duplicate measurements of standards yielded an analytical precision $(1 \sigma)$ of 0.1 and $0.05 \%$ for $\delta^{13} \mathrm{C}$ and $\delta^{18} \mathrm{O}$. The $\delta^{13} \mathrm{C}$ of bulk organic matter was analyzed on an elemental analyzer connected to a MAT-235 IRMS.

Total carbon (TC) and total nitrogen (TN) were measured on a CarloErba CHNS analyzer in the Stable Isotope Laboratory at the University of California, Santa Cruz. Analytical precision based on standards is better than $\pm 0.01 \%$ for TN and $0.02 \%$ for TC. Total 

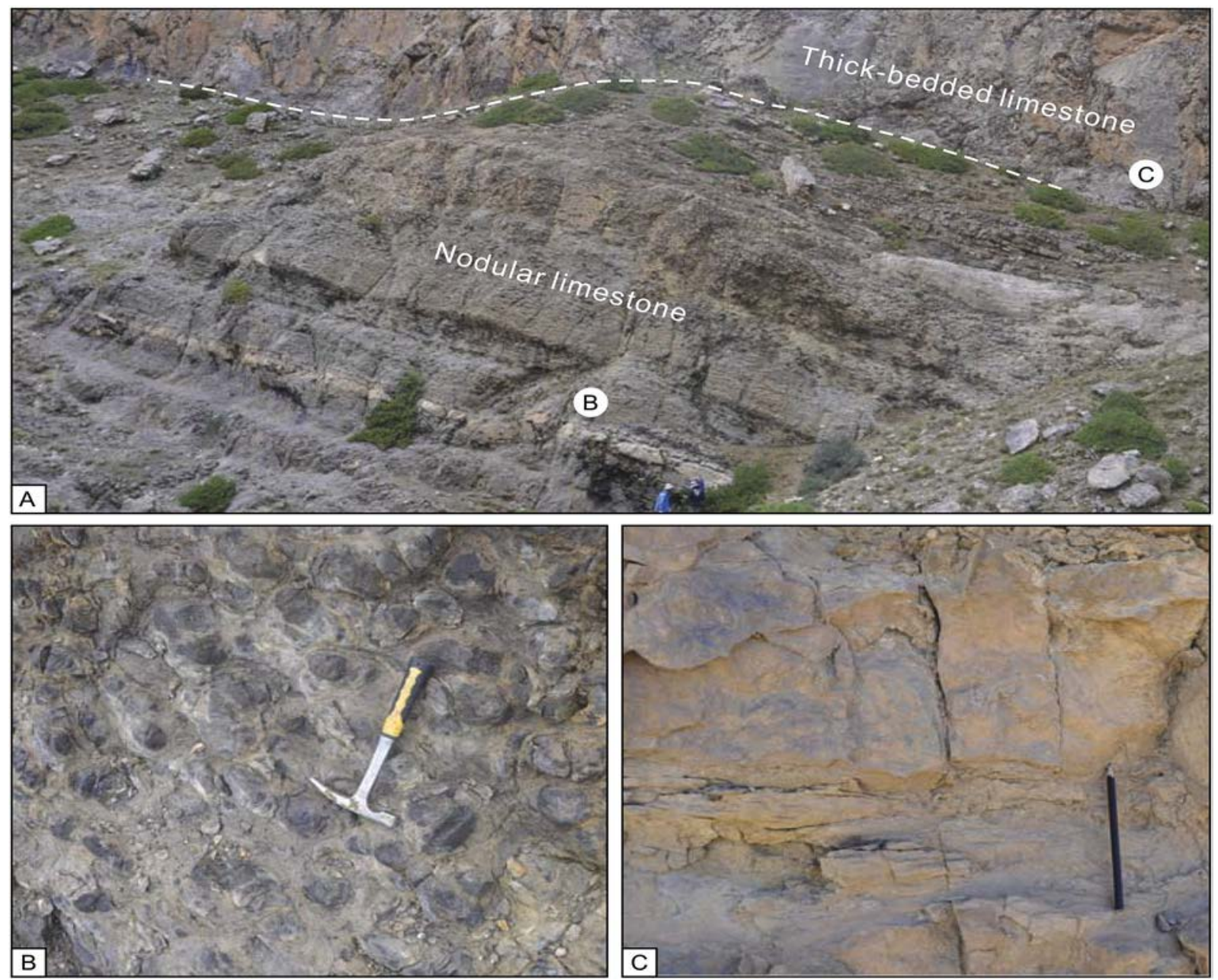

Fig. 2. Outcrop photographs of the Shenkezha section (a) showing: (b) nodular limestone in the lower and middle part; and, (c) thick-bedded to massive limestone in the upper part.

organic carbon (TOC) was calculated by subtracting total inorganic carbon (TIC) from TC. C: N molar ratios were calculated using TOC and TN corrected for the molar weight of $\mathrm{C}$ and $\mathrm{N}$, respectively.

\section{Results}

\subsection{Biostratigraphy}

Thin sections very rich in well preserved LBFs could be firmly correlated with the shallow benthic zones proposed for the Western Tethys (SBZ of Serra-Kiel et al., 1998; BouDagher-Fadel et al., 2015), thus providing firm constraints to the age of the studied strata (Figs. 3, S1). The appearance of Daviesina garumnensis, Miscellanea yvettae, Assilina granulosa, and Ranikothalia thalica indicate an SBZ4 age for the lower part of the nodular limestone. The first appearance of Daviesina tenuis, Daviesina salsa, Miscellanea miscella, and Miscellanea juliettae indicate the base of SBZ5 in the upper part of the nodular limestone. Miscellanea, Ranikothalia, Assilina, and Orbitosiphon are common throughout SBZ5. The transition from SBZ5 to SBZ6 is marked by the first appearance of Alveolina ellipsoidalis and Alveolina pasticillata at the base of the thickbedded limestone, which is characterized by SBZ6 assemblages (Fig. 3).

\subsection{Carbonate microfacies and depositional environments}

Microfacies and organisms are excellent paleoenvironmental proxies as they reflect hydrodynamic conditions, the impact of storms, light, seawater temperature and salinity. Five microfacies (MF) indicative of restricted-lagoon to middle-ramp environments were identified by integrating sedimentological and paleontological observations (Figs. 3, S2). Detailed descriptions and interpretations of each microfacies are provided in supplemental files. The nodular limestone is dominated by nummulitid packstone/rudstone (MF1, Fig. S2a-c) overlain by green algae-nummulitid packstone (MF2, Fig. S2d), indicating progressive deepening of the middle ramp from above to below fair-weather wave base. The topmost strata of the nodular limestone are dominated by bioclastic packstone (MF3, Fig. S2f), with erosive features suggesting storm reworking (Fig. S2e). The thickbedded limestone, characterized by Alveolina packstone with abundant milliods (MF4, Fig. S2g) and rotalids (MF5, Fig. S2h), is interpreted as a restricted-lagoon deposit.

A similar environmental evolution is recorded in other Himalayan sections, where the nodular limestone and the thick-bedded limestone are invariably separated by a disconformity, locally overlain by conglomerate (Li et al., 2017). In the Shenkezha section, these two lithological units document two distinct deepening trends from base to top. The sharp transition from middle-ramp to restricted-lagoon environments conceals an unconformity, although less marked than anywhere else (as discussed below).

\subsection{Isotope geochemistry}

Geochemical data, plotted stratigraphically in Fig. 4, indicate that a gradual negative shift of $\delta^{13} \mathrm{C}_{\text {carb }}$ from $1.2 \%$ o to $-3.7 \%$ o began $\sim 10 \mathrm{~m}$ below the top of the nodular limestone (Fig. 4a). This negative $\delta^{13} \mathrm{C}_{\text {carb }}$ 


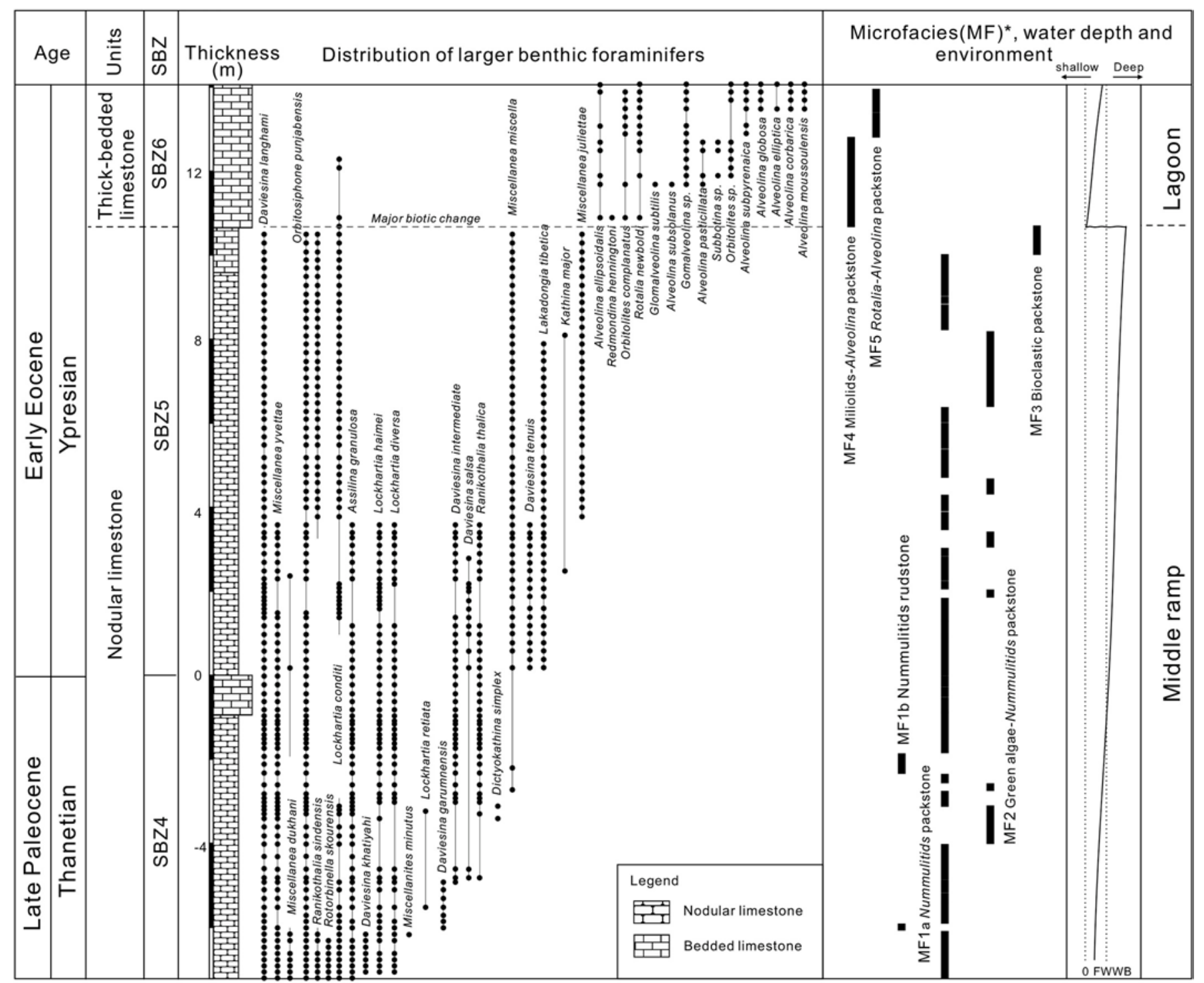

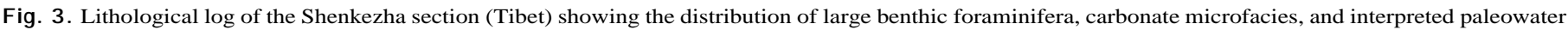

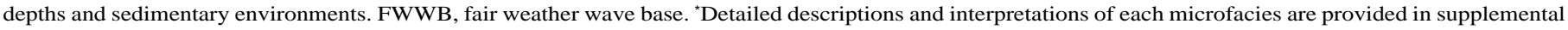
files.

excursion is maintained up to the top of the nodular limestone, decreasing from ca. $-4 \%$ o to $-9 \%$. The base of the thick-bedded limestone documents a sharp shift in $\delta^{13} \mathrm{C}_{\text {carb }}$ from $-7.3 \%$ back to $-1.7 \%$, eventually returning to near stable values of $\sim 1 \%$. Stratigraphically below the CIE, $\delta^{13} \mathrm{C}_{\text {carb }}$ averaged $2 \%$, which is a typical value of carbonates deposited in shallow to deep marine environments (Bains et al., 1999). A slightly negative spike from $1.8 \%$ o to $-1.8 \%$ in $\delta^{13} \mathrm{C}_{\text {carb }}$ was observed below the full onset of the CIE (Fig. 4a). These data are similar to the pre-onset excursion (POE) identified in terrestrial settings by Bowen et al. (2014), although in our case the $\delta^{13} \mathrm{C}_{\text {carb }}$ values did not return to pre-excursion values. Unlike the $\delta^{13} \mathrm{C}_{\text {carb }}$ values, the $\delta^{18} \mathrm{O}_{\text {carb }}$ values are relatively high and stable with an average value of $-6.9 \%$ (Fig. 4b).

Isotope values of bulk organic carbon $\left(\delta^{13} \mathrm{C}_{\text {org }}\right)$ display a trend similar to the $\delta^{13} \mathrm{C}_{\text {carb }}$ record, with a major difference: the CIE onset in $\delta^{13} \mathrm{C}_{\text {org }}$ starts $2 \mathrm{~m}$ lower than in $\delta^{13} \mathrm{C}_{\text {carb }}$ (Fig. 4c). The PETM onset is marked by a gradual negative shift in $\delta^{13} \mathrm{C}_{\text {org }}$ from $-20.5 \%$ to $-25.3 \%$, as for the $\delta^{13} \mathrm{C}_{\text {carb }}$, increasing to $-26.2 \%$ up section. The $\delta^{13} \mathrm{C}_{\text {org }}$ values at the top of the nodular limestone are not as pronounced as in $\delta^{13} \mathrm{C}_{\text {carb }}$ and sharply return to pre-excursion values above the unconformity.

The $\mathrm{C} / \mathrm{N}$ ratio displays a similar trend as carbon-isotope data, being on average 12.9 below the CIE, decreasing abruptly from 15.6 to 4.2 at the CIE onset, notably increasing again across the unconformity, and eventually returning to pre-excursion values in the thick-bedded limestone above (Fig. 4d).

\section{Discussion}

\subsection{Diagenetic effects on shallow water carbonate}

The interstratal circulation of fluids, especially in meteoric environments, can modify the original stable-isotope signature of shallowmarine carbonates especially during major regressions. However, we are confident that the carbon-isotope values from the Shenkezha section were not significantly altered by diagenesis. Evidence of meteoric diagenesis is lacking and optical observations indicate good preservation of larger foraminifers and other fossils in the limestone. The $\delta^{18} \mathrm{O}$ values are relatively high suggesting only minimal alteration of $\delta^{13} \mathrm{C}_{\text {carb }}$ values, if any. The primary $\delta^{13} \mathrm{C}_{\text {carb }}$ values are thus very likely to be 


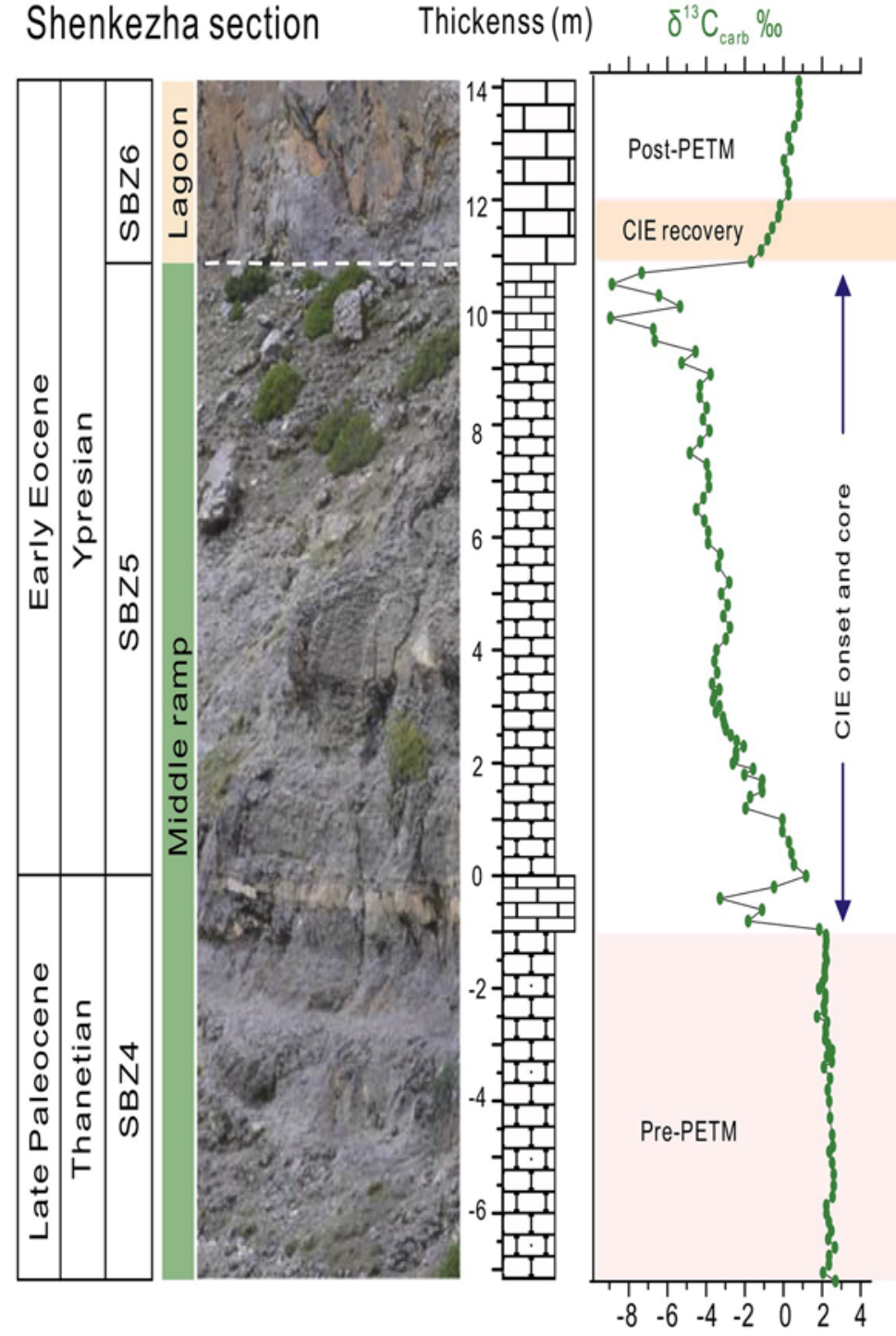

(a)

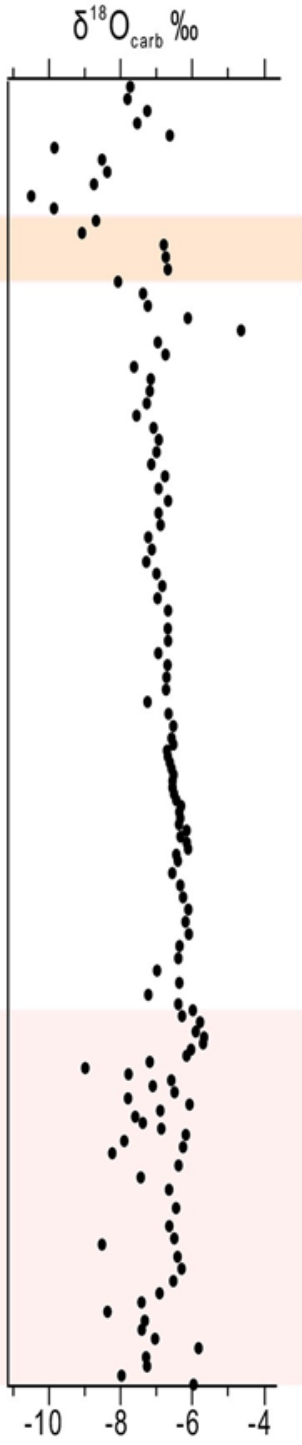

(b)

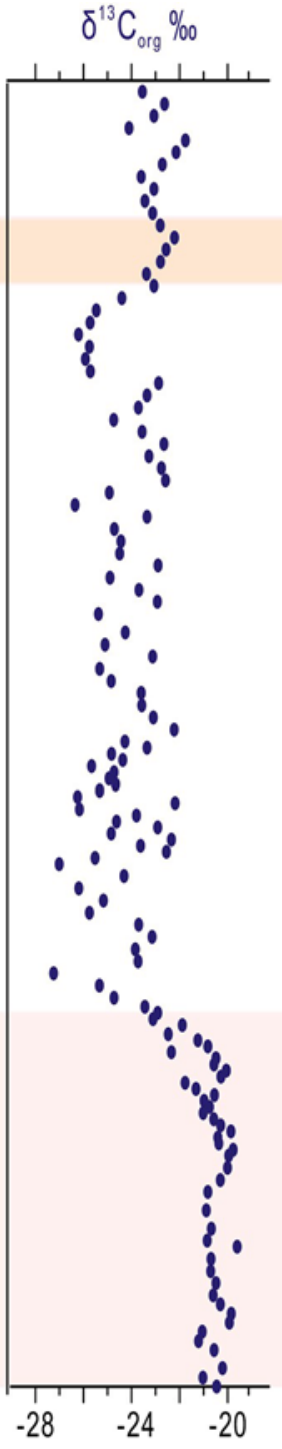

(c)
C:N ratio

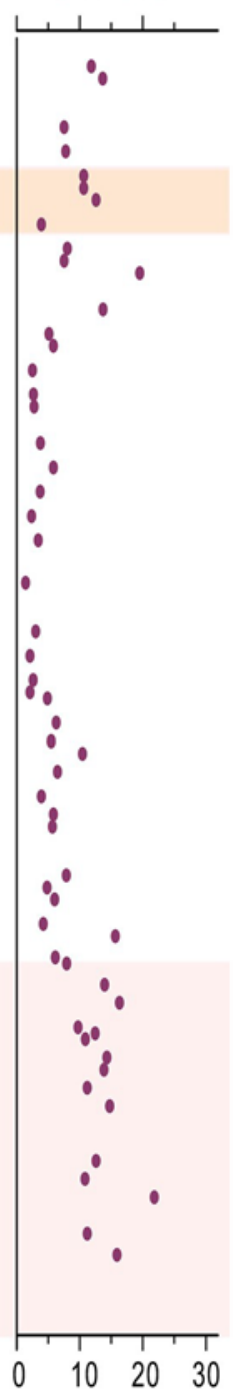

(d)

Fig. 4. Stratigraphic log and geochemical data across the PETM (Shenkezha section, Tibet). The relationships among carbon and oxygen-isotope signatures of the bulk carbonate rock (a, b), organic carbon (c), and the $\mathrm{C} / \mathrm{N}$ ratio (d) are shown.

preserved as also indicated byMn/ $\mathrm{Sr}$ and ${ }^{87} \mathrm{Sr} /{ }^{86} \mathrm{Sr}$ ratios obtained in nearby sections by Zhang et al. (2017). Moreover, the analysis of wellpreserved larger benthic foraminifers with similar $\delta^{13} \mathrm{C}_{\text {carb }}$ isotope record by nanoSIMS confirms that $\delta^{13} \mathrm{C}_{\text {carb }}$ isotope values are primary (Zhang et al., 2020). The only exception may be represented by the most prominent feature observed at the base of thick-bedded limestones in the uppermost part of the carbon-isotope excursion. These layers correspond to a major shift from middle ramp to restricted lagoon environments. Although no obvious subaerial exposure was observed in the field, we speculate that these strongly negative carbon-isotope values might have resulted from meteoric diagenesis related to subaerial exposure.

\subsection{Relative sea-level changes across the PETM}

Relative sea-level rise at PETM onset has been described from other continental margins (Iakovleva et al., 2001; Speijer and Wagner, 2002; Harding et al., 2011; Sluijs et al., 2008b; Sluijs et al., 2014 and references therein), but studies on sea-level changes across the PETM core and recovery have been limited due to the lack of adequate sections covering this time interval. Our study of the quasi-continuous Shenkezha section documents a transgressive trend that began at PETM onset and continued through the CIE core. Above, microfacies testify to a sudden shift from middle-ramp settings in the nodular limestone to restricted-lagoon environments in the thick-bedded limestone (Fig. 3). This transition corresponds to a disconformity suggesting a relative sealevel fall of the order of tens of meters, followed by renewed transgression during PETM recovery documented by the thick-bedded limestone. By comparison with the CIE curve of ODP Site 690B, the hiatus can be assessed to represent no more than a few tens of thousands years.

Changes in relative sea level during the PETM may have been controlled by the interplay of diverse factors, potentially including eustatism, regional tectonics, or variations in carbonate productivity. Changes of ocean-basin volume associated with the North Atlantic Igneous Province, thermal expansion of seawater, melting of small-scale Antarctic alpine glaciers triggered by extreme warming at, or just before, PETM onset have been proposed as mechanisms accounting for eustatic rise (Sluijs et al., 2008b). In the Tethys Himalaya, the relative fall in sea level documented by the disconformity developed close to the 


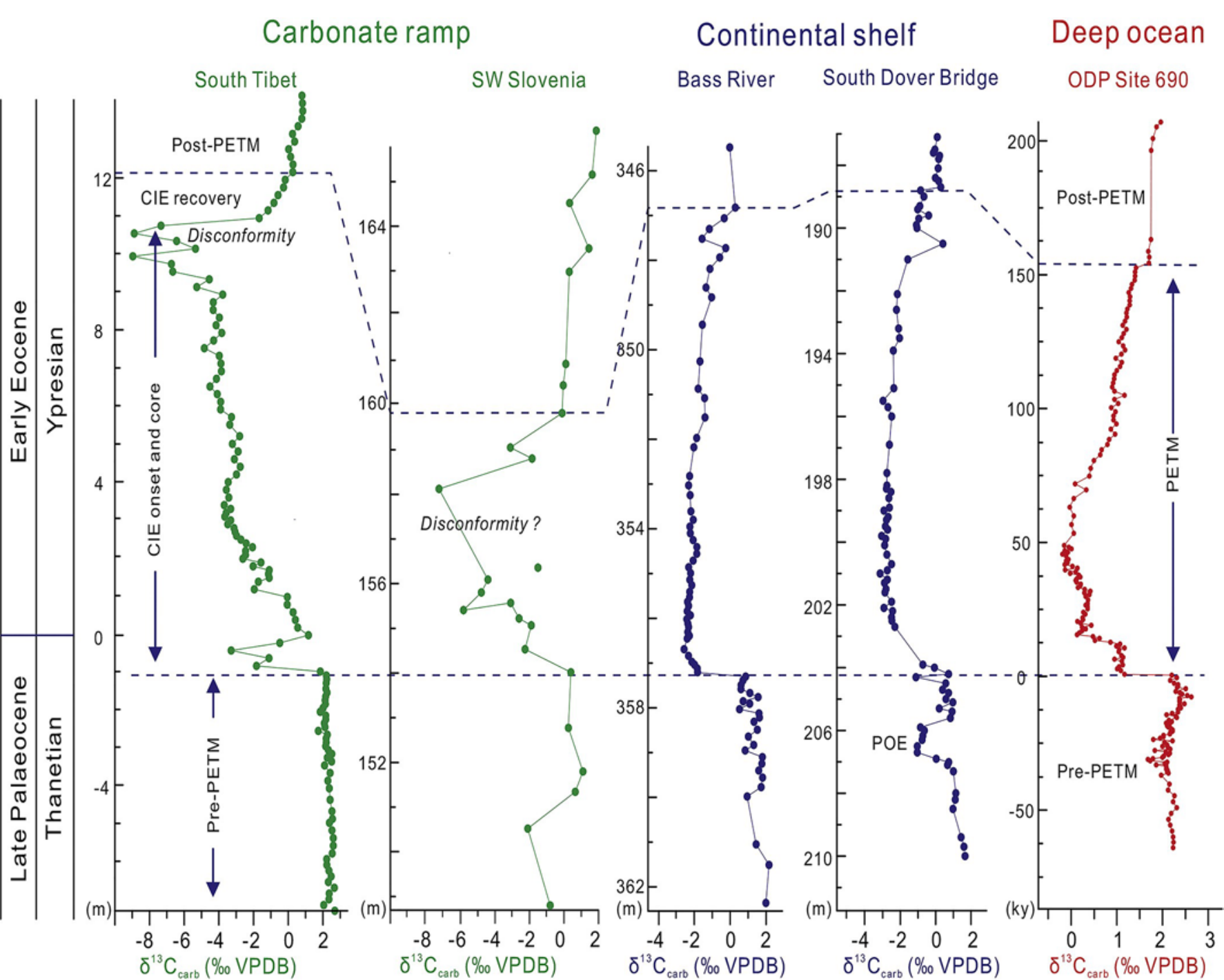

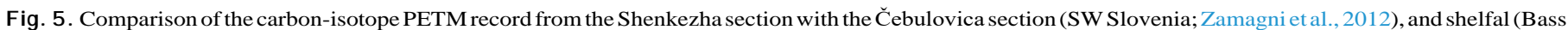

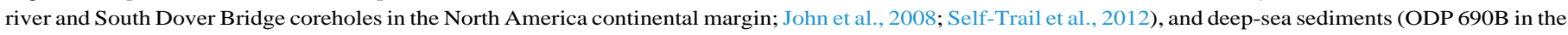
Weddell Sea, Antarctica; Bains et al., 1999).

Paleocene/Eocene boundary and has long been related to the initial stages of the ongoing India-Asia collision (Garzanti et al., 1987), which may have induced significant tectonic uplift of the Indian inner margin a few Ma later than initial collision with Asia (dated as $59 \pm 1 \mathrm{Ma}$; $\mathrm{Hu}$ et al., 2015). Climatic or eustatic components, however, cannot be ruled out (Li et al., 2017).

\subsection{Biotic changes across the PETM}

Global warming during the PETM is associated with major biogeographic and ecologic changes in planktonic and terrestrial ecosystems (McInerney and Wing, 2011). Impacts on shallow-marine benthic faunas, however, are obscured by the general incompleteness of stratigraphic sections. The rate and continuity of deposition (apart for the unconformity) documented in the Shenkezha section, along with the bountiful fossils and good definition of the carbon-isotope excursion, provide a rare opportunity to study the impact of the PETM on shallowmarine fauna.

The larger benthic foraminiferal (LBF) assemblages with Miscellanea, Ranikothalia, Lockhartia, Orbitosiphon and Daviesina show no notable taxonomic change at the CIE onset, across the SBZ4/SBZ5 boundary, or within SBZ5 (as claimed by Zhang et al., 2018). The main taxonomic change is observed at the SBZ5/SBZ6 boundary, at the base of the thick-bedded limestone. This boundary documents the sudden disappearance of Miscellanea, Lockhartia, Ranikothalia, Operculina, Daviesina, Orbitosiphon and the initial dominance of Alveolina and Orbitolites associated with abundant small miliolids and rotaliids. This faunal turnover, marked by the extinction of several major Paleocene LBFs, is recognized over a wide area of the Tethyan realm (Scheibner and Speijer, 2008), although it does not correlate with either the CIE or the Paleocene/Eocene (P/E) boundary. Our data clearly document that the major LBF taxonomic turnover took place between SBZ5 and SBZ6 at PETM recovery, thus notably later than the isotopically defined P/E boundary (International Commission of Stratigraphy; Aubry et al., 2007).

Habitats of LBFs are conditioned by several environmental parameters, including temperature, continental runoff, and water depth (Beavington-Penney and Racey, 2004). During the PETM, sea-surface temperatures rose just prior to CIE onset, quickly reaching maximum through CIE core. Records from equatorial sites suggest a sea-surface temperature (SST) $>36{ }^{\circ} \mathrm{C}$ (Aze et al., 2014; Frieling et al., 2017, 2019). Our data from the Shenkezha section indicate that even such an extreme increase in temperature did not significantly influence LBF assemblages. Another potentially influencing factor might have been 
represented by enhanced continental runoff, resulting in stratification and eutrophic conditions in coastal waters (Beavington-Penney and Racey, 2004). However, the broad carbonate ramps extensively grown in the Tethyan realm during the Paleogene were characterized by strong current activity and redistribution of sediment (Gavrilo et al., 2003), which would have limited the concentration of nutrients and the consequent development of eutrophic anoxic conditions less susceptible to changes in runoff and nutrients. The main taxonomic change in LBF assemblages coincided with the large relative sea-level drop at the SBZ5/SBZ6 boundary, which leads us to infer that reduced water depths, resulting in increasing water motion and light intensity, and possibly exposure, exerted the main control on biological niches and biofacies.

\subsection{Carbon isotope signature of carbonate platforms}

The magnitude of the $\delta^{13} \mathrm{C}_{\text {org }}$ excursion in the Shenkezha section ( 4\%) is comparable to records from other marine bulk organic matter ( $\sim .1 \%$; $n=11$; see comprehensive review by McInerney and Wing, 2011). The magnitude of the bulk-rock $\delta^{13} \mathrm{C}_{\text {carb }}$ excursion ( 7\%o), instead, is larger and relatively ${ }^{13} \mathrm{C}$-depleted than in other continental shelf (2.8-3.5\%o for North America; John et al., 2008; Self-Trail et al., 2012) and deep-sea bulk carbonates (between $2.5 \%$ and $4.0 \%$ ), although comparable to values reported for shallow-marine carbonate platforms (Zamagni et al., 2012; Zhang et al., 2020) (Fig. 5). Studies on modern and ancient carbonate platforms have related low $\delta^{13} \mathrm{C}_{\text {carb }}$ values for carbonate platforms to several factors (Patterson and Walter, 1994; Sanders, 2003; Immenhauser et al., 2008), including: 1) restriction and smaller carbon reservoir size of the platform-top water mass; 2) influence of the local carbon weathering fluxes from the land; 3) early diagenesis of carbonate mud in organic-rich sediments; and, 4) sea-level change.

Deposition of the Shenkezha carbonates took place in shallow-water environments, where restriction of water masses was limited by waveand current-driven exchange between the shallow and open sea. The C/ $\mathrm{N}$ ratio for terrigenous organic matter is typically $>15$, whereas values for marine organic matter are $<10$. In the Shenkezha section, the sharp decrease of the $\mathrm{C} / \mathrm{N}$ ratio from 16 to 4 at PETM onset indicates an abrupt shift to a more marine-influenced source (Fig. 4d), which suggests a decline in the relative amount of terrestrial organic matter because of a greater distance from shore. We conclude that the negative $\delta^{13} \mathrm{C}_{\text {carb }}$ values of Shenkezha carbonates were not influenced by either restriction of water mass or carbon weathering fluxes from the land.

Dissolution of $\mathrm{CaCO}_{3}$ due to organic-matter oxidation may affect the original $\delta^{13} \mathrm{C}_{\text {carb }}$ value and impart low $\delta^{13} \mathrm{C}_{\text {carb }}$ values to carbonate during early diagenesis (Immenhauser et al., 2008). Carbonate strata in the Shenkezha section, however, are dominated by calcium carbonate (>90\%, Zhang et al., 2020) with low TOC values, and an alteration of the original $\delta^{13} \mathrm{C}_{\text {carb }}$ value is thus unlikely.

The strongly ${ }^{13} \mathrm{C}$-depleted values of shallow-marine Shenkezha carbonates might be partly related to eustatically or tectonically-driven change in relative sea level. In the Shenkezha section, a relative sealevel rise coincided with PETM onset and continued through PETM core, then dropped during development of the unconformity during PETM recovery. These fluctuations of relative sea-level may have influenced the $\delta^{13} \mathrm{C}_{\text {carb }}$ value of shallow-marine carbonates (Swart, 2008; Jones et al., 2019).

As relative sea-level rose, middle ramp deposits are buried by deeper water deposits, during PETM onset and through PETM core, depositional environments deepened, and the $\delta^{13} \mathrm{C}_{\text {carb }}$ value became more influenced by deeper-water carbonate and hence more negative. Then relative sea-level fell, and an unconformity developed. As relative sea level rose again during PETM recovery, deeper-ramp environments are replaced by shallower deposits, the ${ }^{15} \mathrm{C}_{\text {carb }}$ values increased to

reflect values typical of shallower-water carbonates. The same extremely negative trend is not observed for organic carbon, probably because much of the old organic carbon could have been remineralized rather than redeposited. Because the organic carbon record is less impacted by redeposition and perhaps also composition, the long-term shape of the CIE of organic carbon may be just as a good a marker for the dissolved inorganic carbon, although with more short-term scatter. Similarly, influence of relative-sea-level change on the increase of $\delta^{13} \mathrm{C}_{\text {carb }}$ values was documented in shallow-water Neogene (Bahamas; Swart, 2008) to upper Ordovician carbonates (Anticosti Island in eastern Canada and Great Basin in Nevada and Utah; Jones et al., 2019). The processes held to be responsible for carbon-isotope excursions during the PETM in our Himalayan case may thus have operated in similar ways in different regions through geological time, which has broad implications for the interpretation of the environmental significance of $\delta^{13} \mathrm{C}_{\text {carb }}$ excursions and associated geochemical perturbations recorded in ancient platform carbonates.

\section{Conclusion}

In the stratigraphically quasi-continuous Tethys Himalayan section studied in detail, relative sea-level began to rise at the onset of the CIE, dated as the SBZ4/SBZ5 boundary, thus revealing the onset of the PETM. Relative sea-level continued to rise through the PETM core, and then dropped during formation of a minor unconformity during PETM recovery. No major biotic change is documented by larger benthic foraminifera at PETM onset or through PETM core. The major taxonomic change is recorded later on at the SBZ5/SBZ6 boundary and during PETM recovery. Relative sea-level change, rather than temperature, exerted the fundamental control on biota. The carbonate ramp was flooded at PETM onset and transgression continued through the PETM core interval, while the $\delta^{13} \mathrm{C}_{\text {carb }}$ was becoming progressively more negative. Relative sea-level fell around the PETM recovery, when middle-ramp environments were unconformably replaced by shallowerwater sediments during PETM recovery. At this stage, $\delta^{13} \mathrm{C}_{\text {carb }}$ values were restored to nearly pre-PETM levels, reflecting the values typical of carbonate sediment produced in proximal shallow-marine environments. Similar processes may have operated in platform settings through much of Earth history, indicating that the geochemical record of shallow-water carbonate platforms may not necessarily reflect global ocean chemistry.

\section{Declaration of Competing Interest}

The authors declare that they have no known competing financial interests or personal relationships that could have appeared to influence the work reported in this paper.

\section{Acknowledgements}

We thank Jingxin Jiangn Colin Carney and Will Rush for their assistance in the field or in the laboratory. Careful reviews by Appy Sluijs and an anonymous reviewer are gratefully acknowledged. This study was financially supported by the National Natural Science Foundation of China (41888101, 41702105), State Key Laboratory of Palaeobiology and Stratigraphy (183115) and China Scholarship Council (201806195034).

\section{Appendix A. Supplymentary data}

\section{References}

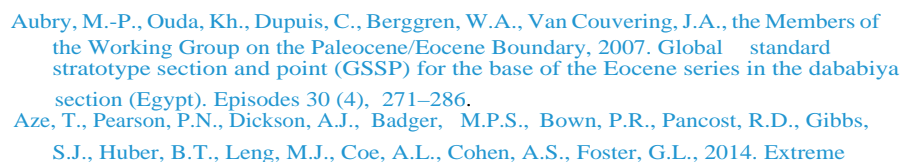

Aubry, M.-P., Ouda, Kh., Dupuis, C., Berggren, W.A., Van Couvering, J.A., the Members of section (Egypt). Episodes 30 (4), 271-286.

S.J., Huber, B.T., Leng, M.J., Coe, A.L., Cohen, A.S., Foster, G.L., 2014. Extreme 
warming of tropical waters during the Paleocene-Eocene thermal maximum. Geology 42, 739-742.

Bains, S., Corfield, R.M., Norris, R.D., 1999. Mechanisms of climate warming at the end of the Paleocene. Science 285, 724-727.

Beavington-Penney, S.J., Racey, A., 2004. Ecology of extant nummulitids and other larger benthic foraminifera: application in palaeoenvironmental analysis. Earth Sci. Rev. 67, 219-265.

BouDagher-Fadel, M.K., Price, G.D., Hu, X., Li, J., 2015. Late cretaceous to early Paleogene foraminiferal biozones in the Tibetan Himalayas, and a pan-Tethyan foraminiferal correlation scheme. Stratigraphy 12, 67-91.

Bowen, G.J., Maibauer, B.J., Kraus, M.J., Röhl, U., Westerhold, T., Steimke, A., Gingerich, P.D., Wing, S.L., Clyde, W.C., 2014. Two massive, rapid releases of carbon during the onset of the Palaeocene-Eocene thermal maximum. Nat. Geosci. 8, 44-47.

Dickens, G.R., Castillo, M.M., Walker, J.C.G., 1997. A blast of gas in the latest Paleocene: simulating first-order effects of massive dissociation of oceanic methane hydrate. Geology 25, 259-262.

Dunham, R.J., 1962. Classification of carbonate rocks according to deposition texture. In: Ham, W.E. (Ed.), Classification of Carbonate Rocks. American Association of Petroleum Geologists, pp. 108-121.

Embry, A.F., Klovan, J.E., 1971. A late Devonian reef tract on northeastern Banks Island. NWT. Bull. Canad. Petrol. Geol. 19, 730-781.

Flügel, E., 2010. Microfacies of Carbonate Rocks: Analysis, Interpretation and Application. Springer, Berlin Heidelberg, New York.

Frieling, J., Gebhardt, H., Huber, M., Adekeye, O.A., Akande, S.O., Reichart, G.-J., Middelburg, J.J., Schouten, S., Sluijs, A., 2017. Extreme warmth and heat-stressed plankton in the tropics during the Paleocene-Eocene thermal maximum. Sci. Adv. 3 (3), e1600891.

Frieling, J., Peterse, F., Lunt, D.J., Bohaty, S.M., Sinninghe Damsté, J.S., Reichart, G.-J., Sluijs, A., 2019. Widespread warming before and elevated barium burial during the Paleocene-Eocene thermal maximum: evidence for methane hydrate release? Paleoceanogr. Paleoclimatol. 34, 546-566.

Gansser, A., 1964. Geology of the Himalayas. Interscience, New York.

Garzanti, E., Baud, A., Mascle, G., 1987. Sedimentary record of the northward flight of India and its collision with Eurasia (Ladakh Himalaya, India). Geodin. Acta 1, 297 312.

Gradstein, F.M., Ogg, J.G., Schmitz, M.D., Ogg, G.M., 2012. The Geologic Time Scale 2012. Elsevier, Amsterdam.

Gavrilov, Y., Shcherbinina, E.A., Oberhansli, H., 2003. Paleocene-Eocene boundary events in the northeastern Peri-Tethys, in Causes and Consequences of Globally Warm Climates in the Early Paleogene. In: Wing, S. L (Ed.), Spec. Pap. Geol. Soc. Am. 369. pp. 147-168.

Harding, I.C., Charles, A.J., Marshall, J.E.A., Pälike, H., Roberts, A.P., Wilson, P.A., Jarvis, E., Thorne, R., Morris, E., Moremon, R., Pearce, R.B., Akbari, S., 2011. Sea-level and salinity fluctuations during the Paleocene-Eocene thermal maximum in Arctic Spitsbergen. Earth Planet. Sci. Lett. 303, 97-107.

Hu, X., Sinclair, H.D., Wang, J., Jiang, H., Wu, F., 2012. Late Cretaceous-Palaeogene stratigraphic and basin evolution in the Zhepure Mountain of southern Tibet: implications for the timing of India-Asia initial collision. Basin Res. 24 (5), 520-543.

Hu, X., Garzanti, E., Moore, T., Raffi, I., 2015. Direct stratigraphic dating of India-Asia collision onset at the Selandian (middle Paleocene, $59 \pm 1 \mathrm{Ma}$ ). Geology 43 (10), 859-862.

Iakovleva, A., Brinkhuis, H., Cavagnetto, C., 2001. Late Palaeocene-early Eocene dinoflagellate cysts from the Turgay Strait, Kazakhstan; correlations across ancient seaways. Palaeogeogr. Palaeoclimatol. Palaeoecol. 172, 243-268.

Immenhauser, A., Holmden, C., Patterson, W.P., 2008. Interpreting the carbon isotope record of ancient shallow epeiric seas: lessons from the recent. Geol. Assoc. Can. Spec. Pap. 48, 137-174.

IPCC, 2013. Climate Change 2013: The Physical Science Basis. Contribution of Working Group I to the Fifth Assessment Report of the Intergovernmental Panel on Climate Change. Cambridge University Press, Cambridge, UK and New York, NY, USA.

John, C.M., Bohaty, S.M., Zachos, J.C., Sluijs, A., Gibbs, S., Brinkhuis, H., Bralower, T.J., 2008. North American continental margin records of the Paleocene-Eocene thermal maximum: Implications for global carbon and hydrological cycling. Paleoceanography 23 (2), PA2217. https://doi.org/10.1029/2007PA001465.

Jones, D.S., Brothers, R.W., Crüger Ahm, A.-S., Slater, N., Higgins, J.A., Fike, D.A., 2019 Sea level, carbonate mineralogy, and early diagenesis controlled $\delta{ }^{13} \mathrm{C}$ records in Upper Ordovician carbonates. Geology 48 (2), 194-199.

Kelly, D.C., Zachos, J.C., Bralower, T.J., Schellenberg, S.A., 2005. Enhanced terrestrial weathering/runoff and surface ocean carbonate production during the recovery stages of the Paleocene-Eocene thermal maximum. Paleoceanography 20, PA4023. https://doi.org/10.1029/2005PA001163.

Komar, N., Zeebe, R.E., 2017. Redox-controlled carbon and phosphorus burial: a mechanism for enhanced organic carbon sequestration during the PETM. Earth Planet. Sci. Lett. 479, 71-82.

Li, J., Hu, X., Garzanti, EB̧ouDagher-Fadel, M., 2017. Shallow-water carbonate responses to the Paleocene-Eocene thermal maximum in the Tethyan Himalaya (Southern Tibet): Tectonic and climatic implications. Palaeogeogr. Palaeoclimatol. Palaeoecol. 466, 153-165.

McInerney, F.A., Wing, S.L., 2011. The Paleocene-Eocene thermal maximum: a perturbation of carbon cycle, climate, and biosphere with implications for the future. Annu. Rev. Earth Planet. Sci. 39, 489-516.

Nicora, A., Garzanti, E., Fois, E., 1987. Evolution of the Tethys Himalaya continental shelf during Maastrichtian to Paleocene (Zanskar, India). Riv. Ital. Paleontol. Stratigr. 92 439-496.

Patterson, W.P., Walter, L.M., 1994. Depletion of 13C in seawater $\Sigma$ C02 on modern carbonate platforms: significance for the carbon isotopic record of carbonates. Geology 22, 885-888.
Penman, D.E., Turner, S.K., Sexton, P.F., Norris, R.D., Dickson, A.J., Boulila, S., Ridgwell, A., Zeebe, R.E., Zachos, J.C., Cameron, A., Westerhold, T., Röhl, U., 2016. An abyssal carbonate compensation depth overshoot in the aftermath of the Palaeocene-Eocene thermal maximum. Nat. Geosci. 9, 575-580.

Sanders, D., 2003. Syndepositional dissolution of calcium carbonate in neritic carbonate environments: geological recognition, processes, potential significance. J. Afr. Earth Sci. 36, 99-134.

Scheibner, C., Speijer, R.P., 2008. Late Paleocene-early Eocene Tethyan carbonate platform evolution — a response to long- and short-term paleoclimatic change. Earth Sci, Rev. 90, 71-102.

Scheibner, C., Speijer, R.P., Marzouk, A.M., 2005. Turnover of larger foraminifera during the Paleocene-Eocene thermal maximum and paleoclimatic control on the evolution of platform ecosystems. Geology 33, 493-496.

Scheibner, C., Rasser, M.W., Mutti, M., 2007. The Campo section (Pyrenees, Spain) revisited: implications for changing benthic carbonate assemblages across the Paleocene-Eocene boundary. Palaeogeogr. Palaeoclimatol. Palaeoecol. 248, 145168.

Schmitz, B., Pujalte, V., 2003. Sea-level, humidity, and land-erosion records across the initial Eocene thermal maximum from a continental-marine transect in northern Spain. Geology 31, 689-692.

Schmitz, B., Pujalte, V., 2007. Abrupt increase in seasonal extreme precipitation at the Paleocene-Eocene boundary. Geology 35, 215-218.

Sciunnach, D., Garzanti, E., 2012. Subsidence history of the Tethys Himalaya. Earth Sci. Rev. 25, 179-198.

Self-Trail, J.M., Powars, D.S., Watkins, D.K., Wandless, G.A., 2012. Calcareous nannofossil assemblage changes across the Paleocene-Eocene thermal maximum: evidence from a shelf setting. Mar. Micropaleontol. 92-93, 61-80.

Serra-Kiel, J., Hottinger, L., Caus, E., Drobne, K., Ferrandez, C., Jauhri, A.K., Less, G., Pavlovec, R., Pignatti, J., Samso, M.J., Schaub, H., Sirel, E., Strougo, A., Tambaregu, Y., Tosquella, J., Zakrevskaya, E., 1998. Larger foraminifera biostratigraphy of the Tethyan Paleocene and Eocene. Bull. Soc. géol. France 169 (2), 281-299.

Sluijs, A., Röhl, U., Schouten, S., Brumsack, H.-J., Sangiorgi, F., Sinninghe Damsté, J.S., Brinkhuis, H., 2008a. Arctic late Paleocene-early Eocene paleoenvironments with special emphasis on the Paleocene-Eocene thermal maximum (Lomonosov Ridge, Integrated Ocean Drilling Program Expedition 302). Paleoceanography 23, PA1S11.

Sluijs, A., Brinkhuis, H., Crouch, E.M., John, C.M., Handley, L., Munsterman, D., Bohaty, S.M., Zachos, J.C., Reichart, G.-J., Schouten, S., Pancost, R.D., Damsté, J.S.S., Welters, N.L.D., Lotter, A.F., Dickens, G.R., 2008b. Eustatic variations during the Paleocene-Eocene greenhouse world. Paleoceanography 23, PA4216. https://doi. org/10.1029/2008PA001615.

Sluijs, A., van Roij, L., Harrington, G.J., Schouten, S., Sessa, J.A., LeVay, L.J., Reichart, G.J., Slomp, C.P., 2014. Warming, euxinia and sea level rise during the PaleoceneEocene thermal maximum on the gulf coastal plain: implications for ocean oxygenation and nutrient cycling. Clim. Past 10, 1421-1439.

Speijer, R.P., Wagner, T., 2002. Sea-level changes and black shales associated with the late Paleocene thermal maximum: organic-geochemical and micropaleontologic evidence from the southern Tethyan margin (Egypt-Israel). Geol. Soc. Am. Spec. Pap. 356, 522-550.

Stassen, P., Dupuis, C., Steurbaut, E., Yans, J., Speijer, R.P., 2012a. Perturbation of a Tethyan coastal environment during the Paleocene-Eocene thermal maximum in Tunisia (Sidi Nasseur and Wadi Mezaz). Palaeogeogr. Palaeoclimatol. Palaeoecol. 317-318, 66-92.

Stassen, P., Thomas, E., Speijer, R.P., 2012b. Integrated stratigraphy of the PaleoceneEocene thermal maximum in the New Jersey Coastal Plain: toward understanding the effects of global warming in a shelf environment. Paleoceanography. https://doi.org/ 10.1029/2012PA002323.

Swart, P.K., 2008. Global synchronous changes in the carbon isotopic composition of carbonate sediments unrelated to changes in the global carbon cycle. Proc. Natl. Acad. Sci. U. S. A. 105, 13741-13745.

Zachos, J.C., Roh, U., Schellenberg, S.A., Sluijs, A., Hodell, D.A., Kelly, D.C., Thomas, E., Nicolo, M., Raffi, I., Lourens, L.J., McCarren, H., Kroon, D., 2005. Rapid acidification of the ocean during the Paleocene-Eocene thermal maximum. Science 308, $1611-$ 1615.

Zachos, J.C., Dickens, G.R., Zeebe, R.E., 2008. An early Cenozoic perspective on greenhouse warming and carbon-cycle dynamics. Nature 451, 279-283.

Zamagni, J., Mutti, M., Ballato, P., Kosir, A., 2012. The Paleocene-Eocene thermal maximum (PETM) in shallow-marine successions of the Adriatic carbonate platform (SW Slovenia). Geol. Soc. Am. Bull. 124, 1071-1086.

Zeebe, R.E., Lourens, L.J., 2019. Solar System chaos and the Paleocene-Eocene boundary age constrained by geology and astronomy. Science 365, 926-929.

Zeebe, R.E., Zachos, J.C., 2013. Long-term legacy of massive carbon input to the Earth system: Anthropocene versus Eocene. Philos. Trans. Series A Math. Phys. Eng. Sci. 371, 20120006.

Zeebe, R.E., Ridgwell, A., Zachos, J.C., 2016. Anthropogenic carbon release rate unprecedented during the past 66 million years. Nat. Geosci. 9, 325-329.

Zhang, Q., Wendler, I., Xu, X., Willems, H., Ding, L., 2017. Structure and magnitude of the carbon isotope excursion during the paleocene-eocene thermal maximum. Gondwana Res. 46, 114-123.

Zhang, Q., Willems, H., Ding, L., Xu, X., 2018. Response of larger benthic foraminifera to the Paleocene-Eocene thermal maximum and the position of the Paleocene/Eocene boundary in the Tethyan shallow benthic zones: evidence from Tibetan Himalaya. Geol. Soc. Am. Bull. 131, 84-98.

Zhang, Q., Ding, L., Kitajima, K., Valley, W., Zhang, B., Xu, X., Willems, H., Klügel, A., 2020. Constraining the magnitude of the carbon isotope excursion during the Paleocene-Eocene thermal maximum using larger benthic foraminifera. Glob. Planet. Chang. 184. https://doi.org/10.1016/j.gloplacha.2019.103049. 